\title{
Makna Lupus bagi Odapus: Perspektif Komunikasi Kesehatan Islam
}

\author{
Septa Agustina \\ Institut Agama Islam Negeri Bengkulu, Indonesia
}

Korespondensi dengan Penulis:

Septa Agustina: Telp. 089633034046

E-mail: septaagustina91@gmail.com

Keywords:
Meaning of
Lupus,
Intrapersonal,
Health
Communication,
Islam.

Kata kunci: Makna Lupus, Intrapersonal, Komunikasi kesehatan, Islam.

\section{Abstract}

The meaning becomes one part of communication. The meaning comes from human interpretation and makes humans to contemplate the experiences that occur during their lives. The meaning of Lupus for Odapus (people with lupus) is the process of interpretation in Odapus against Lupus both positive and negative. This study aims to determine the meaning of lupus for Odapus. As for scientific writing, it uses a qualitative-fenomenolgy paradigm. The method used was in-depth interviews, observations and documentation. The results of data analysis conducted on the three informants that the meaning of pain for Odapus through intrapersonal communication becomes the main thing for them to get closer to Allah, especially in the view of Islamic health communication. Lupus experienced by odapus allows them to view life more positively and reflect on every mistake. The three Odapus informants interpreted lupus illness / illness in their lives as a gift from God Almighty (faith), changing a healthier lifestyle, can strengthen communication in life partners and give effect to Odapus behavior such as enthusiasm, optimism, healing, patience and prejudice towards God who wants to alleviate and erase all sins them as Odapus.

\section{Abstrak}

Makna merupakan salah satu bagian terpenting dari komunikasi. Makna berasal dari interpretasi manusia dan membuat manusia untuk merenungi pengalaman yang terjadi dihidupnya. Makna Lupus bagi Odapus (orang dengan lupus) merupakan proses penafsiran dalam diri (intrapersonal) Odapus terhadap penyakit Lupus baik dalam positif maupun negatif. Penelitian ini bertujuan untuk mengetahui makna lupus bagi Odapus dari perspektif Islam. Adapun dalam penulisan ilmiah ini menggunakan paradigma kualitatif-fenomenologi. Metode yang digunakan adalah wawancara mendalam, pengamatan dan dokumentasi. Hasil analisis data yang dilakukan peneliti terhadap ketiga informan 
dalam pandangan komunikasi kesehatan Islam menunjukkan bahwa makna sakit bagi Odapus menjadi hal utama bagi mereka untuk mendekatkan diri pada Allah SWT. Lupus yang dialami odapus membuat mereka dapat memandang hidup lebih positif dan merenungi akan setiap kesalahan. Adapun ketiga informan Odapus memaknai sakit lupus dalam hidup mereka adalah sebagai anugerah dan ujian dari Allah SWT (keimanan), mengubah gaya hidup lebih sehat, mempererat komunikasi pada pasangan dan mempengaruhi perilaku Odapus seperti semangat, optimis sembuh, bersabar dan berprasangka baik terhadap Allah yang ingin meringankan dan menghapus segala dosa penyandang lupus.

\section{PENDAHULUAN}

Kesehatan menjadi hal terpenting bagi setiap individu dalam menjalani hidup. Terutama saat dihadapi dengan berbagai penyakit yang tidak hanya menyerang fisik melainkan juga psikis/mental seseorang. Autoimun adalah satu dari berbagai penyakit yang mengalami peningkatan dan menyerang sistem kekebalan tubuh manusia. Berdasarkan data yang dihimpun dari Amerika, sebanyak 50 juta jiwa mengidap autoimun dan akibatnya lebih dari $75 \%$ penderita autoimun adalah perempuan yang menjadi salah satu penyebab kematian perempuan di bawah umur 65 Tahun. ${ }^{1}$ Penyakit autoimun saat ini mempengaruhi secara kolektif hingga 5-10\% dari populasi dunia dikarenakan autoimun merupakan penyakit kronis. ${ }^{2}$

Salah satu jenis penyakit autoimun yang saat ini menjadi fenomena adalah autoimun Lupus. Lupus menyerang organ jaringan tubuhnya sendiri, dikarenakan sistem kekebalan tubuh manusia yang berlebih. Berdasarkan organisasi dunia WHO, autoimun Lupus setiap tahun selalu mengalami peningkatan dan telah mencapai 5 juta kasus. Hal inilah yang membuat autoimun Lupus menjadi perhatian masyarakat dan dunia medis. Pada tahun 2014 sebanyak 1.169 kasus dengan jumlah 200 orang meninggal dunia (17\%). Di tahun 2015 jumlah kasus lupus meningkat menjadi 1.336, akan tetapi jumlah pasien meninggal menurun sekitar 110 orang (8,2\%). Namun di tahun 2016 meningkat hampir dua kali lipat di banding 2014, diketahui terdapat 2.166 kasus lupus dengan jumlah pasien yang meninggal 550 orang (25\%). ${ }^{3}$ Saat dibandingkan dengan data

\footnotetext{
${ }^{1}$ Siska \& Ahmad,"Ketabahan Pada Wanita Penderita Lupus", Jurnal Psikologi UNDIP.2014. hlm.3

${ }^{2}$ American Autoimmune Related Disease Association. 2010. Autoimmune Statistic.

Autoimmune American, http://aarda.org/autoimmune-information/autoimmune-statistic/. akses 7 April 2020

${ }^{3}$ Infodatin-Kemenkes, https;//www.Infodatin-kemenkes.com diakses 11 Nov 2017
} 
selama dua dekade, Lupus di Indonesia mengalami peningkatan dan telah tersebar diberbagai Provinsi. ${ }^{4}$ Provinsi Bengkulu adalah salah satu Provinsi yang terkena Lupus, berdasarkan laporan data yang penulis terima bahwa dari tahun 2015-2017 jumlah penyandang Lupus juga mengalami peningkatan yakni berkisar 36 kasus, 2016 (144 kasus) dan ditahun 2017 (534 kasus). ${ }^{5}$

Ketika individu berada dalam kondisi sehat dan sakit tentu akan menghadapi berbagai reaksi. Jika individu dalam keadaan sakit maka dampak yang dirasakan tidak hanya fisik tetapi juga mempengaruhi kondisi psikologis dan sosial mereka. Penyakit yang ada didalam tubuh membuat seseorang merasa tidak nyaman dengan dirinya sendiri. Disaat orang lain dapat melakukan kegiatan, individu yang tidak dalam keadaan sehat (sakit) harus membatasi diri dalam beraktivitas seperti bekerja atau pun kegiatan lainnya. Dengan begitu, kata sehat menjadi sangat mahal bagi mereka khususnya orang dengan Lupus (Odapus).

Seperti halnya Odapus Bengkulu dalam menjalani aktivitas pengobatan, harus melakukan kontrol rutin di rumah sakit dan mengkonsumsi obat-obatan untuk mengurangi rasa sakit pada tubuh. Beberapa hal rutin tersebut dijalani agar tidak membuat mereka stress dalam menjalani hidup, jika Lupus tidak tertangani dengan baik maka akan membuat Odapus menjadi depresi hingga Bunuh diri. ${ }^{6}$ Penyakit lupus tidak hanya menyerang satu jenis organ melainkan dapat menyerang organ vital tubuh manusia seperti otak, jantung, ginjal, retina, jaringan kulit, sendi dan beberapa organ lainnya.7 Djobaeri meyakini sebanyak $40 \%$ penderita lupus biasanya terkena gangguan secara psikologi. ${ }^{8}$

Hidup adalah sebuah proses yang harus dijalani oleh umat manusia di dunia, hal utama selain menjaga hubungan antar sesama manusia dan Allah SWT adalah bagaimana individu bisa menerima kondisi diri sendiri termasuk dalam menerima sebuah penyakit. Penyakit lupus yang dialami oleh Odapus seringkali menimbulkan berbagai pengalaman emosi yang berdampak

\footnotetext{
${ }^{4}$ Risky\&Dyah, “.Hub.Keterparahan Penyakit dan Kelelahan Pasien SLE”, Unnes Journal Public Health Vol. 5 (3),2016. hlm. 222

${ }^{5}$ Agustina Septa,"Komunikasi Interpersonal Odapus dan Keluarga", Tesis, (Bengkulu:Universitas Bengkulu, 2019), hlm.6

"Sly,"Tidak kuat derita penyakit",Rakyat Bengkulu,1 Agustus 2018. www.HarianRakyatBengkulu/Tidak-kuat-menderita-penyakit. Diakses 3 Agustus 2018

${ }^{7}$ Castle Katherine," Illness Narratives of Woman With SLE", Disertation, (Amerika:University of Nebraska-Lincoln,. 2015), hlm.1 diakses Nov. 2017

${ }^{8}$ Tty,"Lupus Yang Misterius", Okezone.15 Mei 2008. https://lifestyle.okezone.com/lupus-yangmisteriusz. Diakses 5 Agustus 2018
} 
negatif seiring dengan perjalanan penyakit tersebut. Sehingga permasalahan terkait emosi menjadi penting ketika berhadapan dengan kenyataan disaat individu berharap kesembuhan. ${ }^{9}$

Sebagai individu yang membutuhkan waktu untuk bisa merenungi hal yang telah terjadi, maka komunikasi intrapersonal begitu berperan pada Odapus. Komunikasi intrapersonal merupakan komunikasi yang berbicara dari hati individu kepada dirinya sendiri. Proses internal dalam komunikasi intrapersonal melewati empat tahapan sensasi, persepsi, memori dan berpikir. ${ }^{10}$ Melalui komunikasi intrapersonal memberikan kesempatan untuk memaknai kondisi diri mereka saat ini. Terkait hal ini, intrapersonal menjadi salah satu bagian dalam komunikasi kesehatan khususnya terapi diri. Komunikasi kesehatan intrapersonal tidak hanya sebatas pada proses pengiriman pesan melainkan juga pendekatan melalui proses makna. Menurut Viktor Frankl, makna adalah sesuatu yang berharga, penting sekalipun seseorang mengalami penderitaan/sakit dan bagaimana seseorang memberikan nilai pada hidup. ${ }^{11}$

Kajian komunikasi kesehatan saat ini menjadi salah satu kajian ilmiah yang diperhitungkan di Indonesia. Jika biasanya masalah kesehatan diselesaikan secara ilmiah, maka kesehatan juga membutuhkan pandangan yang berbeda. Dalam hal ini, paradigma kesehatan holistik yang bersumber dari islam digunakan untuk memahami manusia ketika mengalami sakit. Ketika individu di diagnosa oleh dokter menderita suatu penyakit, maka yang harus dilakukan adalah berdoa dan berfikir bahwa disaat seseorang terkena penyakit maka ini menjadi tanda sebagai penggugur dosa. ${ }^{12}$ Faktanya bisa dilihat bahwa sebagian besar penyakit menimbulkan penderitaan, hanya saja penderitaan yang ada dapat mendorong seseorang untuk tahu akan makna hidupnya. Dalam praktiknya, seorang penderita penyakit menjadi komunikator dan komunikan, maka proses umpan balik terjadi dalam diri penderita penyakit.

Maka permasalahan kesehatan yang dihadapi oleh Odapus menjadi hal penting untuk di perhatikan, mengingat penyakit lupus tidak dapat diremehkan. Definisi komunikasi kesehatan begitu beragam sesuai dengan tujuan yang ingin dicapai. Proses pengiriman pesan yang dilakukan ini untuk mempengaruhi perilaku dalam menjaga kesehatan. Hal ini senada dalam pandangan Islam, konsep al-Qur'an mengenai komunikasi kesehatan pun bertujuan pada

\footnotetext{
${ }^{9}$ Ahyani,"Regulasi Emosi Odapus", Jurnal Psikologi Undip, Vol.8 No.1,Juni 2012. akses pada 3 Maret 2018

${ }^{10}$ Rahkmat Jalaludin, Psikologi Komunikasi, (Bandung: Remaja Rosdakarya, 2012). hlm.48-72.

${ }^{11}$ Bastaman H.D, Logoterapi:Psikologi untuk menemukan makna hidup, (Jakarta:Grafindo, 2007).

${ }^{12}$ Hanny zainal,dkk.__. Sakitku ibadahku.hlm.13.
} 
perubahan perilaku. Untuk itu, al-Quran adalah petunjuk, obat dan pembeda sebagai media komunikasi yang menjadi salah satu fitrah manusia. ${ }^{13}$

Komunikasi intrapersonal sebagai komunikasi kesehatan juga berlaku pada pemaknaan terhadap rasa sakit. Dengan memahami makna lupus bagi Odapus, maka menjadi penting agar proses Odapus mendapatkan kesembuhan. Untuk itu, komunikasi kesehatan dapat memberikan kesadaran bagi individu mengenai masalah kesehatan, resiko dan solusi kesehatan. Jika dilihat dari perspektif Islam, maka terdapat dalam diri manusia sesuatu yang terlihat dan juga tidak terlihat, agar dapat memaknai keseluruhan sistem dalam tubuh manusia fisik-nonfisik, hingga materi dan immateri terkait sikap kesehariannya. Dengan begitu, masalah keimanan, pola konsumsi dan pola hidup menjadi dasar komunikasi kesehatan dalam pandangan Islam. Hal ini dapat dilakukan individu melalui komunikasi intrapersonal dengan cara memaknai sakit dalam hidupnya, dengan begitu akan memberikan ketenangan secara batin dan memberi dampak positif pada kesehatan secara fisik maupun mental.

Terkait dengan hal ini, Bengkulu menjadi salah satu kota yang memiliki jumlah Odapus yang tidak sedikit, apalagi sebagian besar berasal dari kelas ekonomi menengah ke bawah. Penyakit autoimun (Lupus) menjadi salah satu fenomena dengan jumlah kasus yang selalu meningkat setiap tahunnya, untuk itu terdapat beberapa penelitian terdahulu yang mengkaji mengenai lupus diantaranya Catherine14, Ayu15, Judha16, Agustin17, dan Atikah18, namun masih jarang penelitian yang mengkaji makna lupus dibidang komunikasi kesehatan dalam perspektif Islam.

Peneliti berasumsi bahwa hadirnya komunikasi kesehatan Islam akan membuat perilaku Odapus menjadi lebih baik serta memberikan pemahaman mengenai sehat secara fisik, rohani,

\footnotetext{
${ }_{13}$ Rakhmat Jalaludin, Islam Aktual,( Bandung: Mizan, 1991). hlm. 76.

${ }^{14}$ Castle Katherine,"Illness Narratives of Woman With SLE", Disertation, (Amerika:University of Nebraska-Lincoln,. 2015), hlm.1 diakses Nov. 2017
}

15 Rizky Ayu Fandika, "Hubungan Keparahan Penyakit,Aktivitas dan Kualitas Tidur Pasien SLE", Unnes Journal of Public Health, Vol,5, No.3. hlm. 221-229.

16 M.Judha, "Pencarian Makna Hidup Klien Terdiagnosa Lupus Eritematosus Sistemik Dengan Perspektif Maslow dan Henderson", Jurnal Keperawatan indonesia,Vol.13, No.3. hlm.145-152.

17 Agustin Wahyuningsih,"Kesejahteran Psikologis Pada Odapus Wanita Usia Dewasa Awal Berstatus Menikah", Jurnal Psikologi Klinis dan Kesehatan mental, Vol.1, No.3, 2012. hlm.154-159.

18 Atikah Fatmawati, "Regulasi Diri Pada Penyakit Kronis-SLE:Kajian Literatur", Jurnal keperawatan Indonesia, Vol.21, No.1, 2018.hlm.43-50 
dan spiritual. Terkait dengan kata spiritual, para ahli medis dan ahli kesehatan jiwa melakukan penelitian mengenai dampak spiritual keagamaan terhadap penyembuhan pasien. Hasil penelitian menunjukkan jika religiusitas berdampak pada proses penyembuhan pasien, misalnya ibadah, berdoa serta zikir menjadi alat terapi bagi pasien. ${ }^{19}$ Dapat kita lihat bahwa beberapa bentuk penyembuhan ini dilakukan secara intrapersonal.

Tidak hanya sebatas ketertarikan peneliti terhadap fenomena penyakit autoimun, tujuan dari penulisan ini ingin melihat seberapa besar makna Lupus bagi Odapus dalam hidup mereka. Seperti yang diketahui bahwa arti dari kata makna merupakan hasil dan pengalaman individu. Hasil penulisan ilmiah ini pun diharapkan dapat memberikan kontribusi dan informasi bagi masyarakat awam disaat ketika mereka atau salah satu anggota keluarga terdiagnosa lupus atau penyakit lainnya. Melalui bidang komunikasi kesehatan dalam pandangan Islam, para Odapus atau mereka yang mengalami hal yang sama diharapkan dapat meningkatkan kualitas hidup dan memahami makna hidup sesungguhnya dibalik penyakit yang mereka alami.

\section{METODE}

Dalam melakukan tulisan ilmiah ini, peneliti menggunakan metode penelitian agar dapat memudahkan peneliti berada di lapangan. Adapun metode dalam penulisan ilmiah ini menggunakan metode kualitatif-fenomenologi. Studi fenomenologi ini menelaah kesadaran individu berdasarkan pengalaman yang mereka alami. Adapun teknik pengumpulan data yang dilakukan dengan observasi partisipan melalui pengamatan, wawancara mendalam yang bersifat terbuka dan dokumentasi baik primer dan sekunder.

Berdasarkan sumber informan, peneliti menggunakan teknik purposive sampling. Adapun kriteria informan dalam penelitian ini adalah (1). Odapus yang berumur 20-45 tahun, (2). Odapus yang sudah memiliki penyakit Lupus lebih dari tiga tahun, dan (3). berasal dari Kota Bengkulu. Mereka adalah Odapus Renti, Diana, dan Nancy. Penulisan ini berangkat dari upaya untuk mencari penjelasan tentang peristiwa sosial yang didasarkan pada perspektif dan pengalaman orang yang diteliti. Penulisan ini menggunakan teknik analisis yang mengikuti konsep Miles dan Huberman ${ }^{20}$, selanjutnya data yang ada dianalisis melalui proses reduksi, display dan verifikasi data. Analisis ini dilakukan secara interaktif dan berlangsung secara terus menerus pada setiap tahap penulisan sampai tuntas untuk memperoleh simpulan penelitian.

\footnotetext{
${ }^{19}$ Uud Wahyudin, Komunikasi Kesehatan: Merawat Kesehatan Pandangan Islam, (Bandung:Remaja Rosdakarya, 2018). hlm.64.

${ }^{20}$ Emzir, Metodologi penelitian kualitatif:analisis data, (Jakarta :Rajawali pers, 2018).hlm.134.
} 


\section{HASIL DAN PEMBAHASAN}

Komunikasi merupakan proses pengiriman pesan yang berasal dari komunikator kepada komunikan. Sebagai makhluk sosial, kita perlu menjalin relasi dengan orang lain, yang artinya kita harus selalu menerima tanggapan secara aktif. Menurut Deddy Mulyana, komunikasi adalah proses penyampaian pesan yang akhirnya mencapai kesamaan makna dan penerapan komunikasi tidak hanya sekedar komunikasi sehari-hari melainkan berbagai jenis komunikasi salah satunya ialah komunikasi kesehatan. ${ }^{21}$ Komunikasi kesehatan merupakan komunikasi yang berfokus pada individu dalam memelihara kesehatan. Proses komunikasi pun tidak hanya memberikan sebuah pesan namun juga menghasilkan makna, karena sebagai manusia kita sering memberikan makna pada pesan yang kita terima.

Salah satu bentuk komunikasi yang terjadi pada manusia ialah komunikasi intrapersonal. Komunikasi intrapersonal berhubungan erat pada diri manusia sendiri yang menyangkut batiniah termasuk dalam hal memaknai sesuatu yang terjadi dalam hidup individu, karena di dalamnya terdapat proses pengiriman dan penerimaan pesan dalam diri pribadi individu. Ronald dalam bukunya Uchajana (1993) mengatakan bahwa komunikasi intrapersonal adalah komunikasi yang ada di dalam diri seseorang seperti berbicara pada diri sendiri, mengamati dan memberi makna (intelektual dan emosi) kepada lingkungan.22 Artinya komunikasi intrapersonal terjadi melalui berbagai tahap yang awalnya individu berbicara pada diri sendiri kemudian terdapat dialog yang ditanggapi dalam diri individu, sehingga timbul persepsi dan terdapat pengertian (makna) yang mana terjadilah proses data dan umpan balik dalam diri individu dengan berbagai hal yang dirasakan seperti rasa sakit, penyakit dan pengobatan. Dengan begitu, komunikasi dalam memaknai sebuah penyakit menjadi salah satu bagian dari pengertian komunikasi kesehatan.

Menjaga kesehatan tubuh merupakan kewajiban setiap orang, berbagai cara yang dilakukan untuk mencapai kondisi sehat seperti olahraga dan makan-makanan yang sehat. Namun selain kesehatan fisik, menjaga kesehatan mental juga penting untuk dilakukan apalagi di jaman sekarang banyak orang mengalami gangguan mental. Untuk itu, salah satu upaya menjaga kesehatan mental ialah dengan memaknai apa yang terjadi dalam kehidupan. Mengingat kehidupan manusia tidak selamanya dipenuhi dengan kesenangan namun juga penderitaan seperti halnya dalam keadaan sakit.

\footnotetext{
${ }^{21}$ Mulyana, Deddy. Komunikasi Kesehatan:Pemikiran dan Penelitian (Bandung:Rosdakarya,2018).hlm.2.

22 Puji \& Hanafi," Meaning of Illness dalam perspektif Islam", Jurnal Komunikasi Islam, Vol.6,2016.

hlm.324.
} 
Semakin banyak persoalan pada dunia kesehatan maka dalam cara pandang kesehatan terhadap manusia dan penyakit pun tidak hanya melibatkan dunia medis. Terdapat paradigma yang mengungkapkan bahwa isu kesehatan tidak hanya dapat diselesaikan melalui cara ilmiah. Melainkan dapat dilihat dengan pandangan lain agar kenyataan atau realita hidup dapat dipahami. Bahkan WHO merumuskan definisi kesehatan dengan memasukkan kata rohani dan spiritual sebagai salah satu komponen dalam memperoleh kesehatan ${ }^{23}$. Senada dengan hal tersebut, pandangan atau paradigma komunikasi kesehatan secara Islam atau holistic merupakan sebuah cara pandang menyeluruh dalam mempersepsi realitas untuk mengisi kekosongan pemaknaan dan paradigma dalam memahami realitas dan sains modern.

Al-Quran menyebut komunikasi sebagai salah satu fitrah manusia, dengan adanya paradigma kajian sains holistic berasas spiritual maka agama dapat menjadi salah satu kontributor terhadap dunia kesehatan. Melalui bidang ilmu komunikasi kesehatan dari perspektif Islam, masukkan dari banyak penelitian bidang kesehatan lebih menekankan pada aspek psikis/sosial atas penggunaan obat non-medis.

Dalam sebuah terminologi Islam, Shihab (1996) telah menjelaskan bahwa manusia diistilahkan dengan basyar (manusia) dan insan (jiwa dan raga).24 Dalam paradigma sains holistic yang dilahirkan oleh Islam, memiliki pandangan bahwa dalam diri manusia ada sesuatu yang tampak namun juga ada keunikan tersembunyi yang tidak terdeteksi oleh sains modern. Dalam diri tubuh manusia terdapat beberapa aspek dalam diri manusia yakni aspek biofisik (tubuh/organ), psikis (emosi dan perasaan), spiritual (fitrah ketuhanan) yang jika salah satu aspek diabaikan maka berdampak pada masalah kesehatan. 25

Hal ini sejalan dengan pendapat Franklin yang mengatakan bahwa mengarahkan diri pada kehidupan di dimensi ragawi, kejiwaan dan spiritual. ${ }^{26}$ Maka paradigma komunikasi kesehatan holistic memandang secara utuh keseluruhan sistem dalam tubuh manusia, fisik-nonfisik, materi dan immateri. Istilah yang mendasari paradigma kesehatan holistic ialah masalah keimanan, kecenderungan beragama yang kuat akan mempengaruhi terhadap ketenangan jiwa atau batin dan memiliki korelasi terhadap kesehatan fisik ataupun mental seseorang.

Kita ketahui bahwa ketika manusia mendapatkan penyakit didalam tubuhnya, maka dosa yang ada digugurkan oleh Allah SWT. Hanya terkadang sebagai manusia tentu suka lupa disaat

\footnotetext{
${ }^{23}$ Rustandi Dudi," Meneropong Paradigma Kesehatan",Jurnal Observasi Kajian Komunikasi dan Informatika, vol 7 no 1, 2009. hlm.44.

${ }^{24}$ Dudi, hlm. 40

${ }^{25}$ Hanny Aceng ,dkk., "Sakitku Ibadahku”,(Jakarta : ThinkSmart,2011). hlm.15.

${ }^{26}$ Sri Ni Ketut, "Logoterapi: Pendekatan untuk hidup Bermakna”, (Bali: Udayana,2017).hlm.4.
} 
mengalami sakit hanya dimaknai sebagai penderitaan yang tak kunjung sembuh. Sakit hadir ketika seseorang kurang bisa menjaga kesehatan tubuh atau karena terlalu lama dan lelah bekerja sampai membuat seseorang mengalami stress hingga depresi dan merasa tidak berdaya menjadi faktor seorang Odapus bunuh diri, namun faktor bunuh diri tidak hanya terkait dengan masalah obat-obatan melainkan juga dari faktor lingkungan sosial hingga masalah perekonomian. Mereka yang tidak kuat menghadapi penyakit memilih untuk melakukan bunuh diri. Artinya mental seseorang yang terkena penyakit kronis, membuat mereka tidak sanggup menghadapi dan menahan sakit yang di derita.

Informan yang pertama Odapus adalah Renti. Saat terdiagnosa lupus oleh dokter, ia tidak tahu tentang penyakit tersebut dan menganggap bahwa umurnya tidak akan lama karena saat itu ia hanya berfikir tentang kematian. Namun seiring berjalannya waktu, ia menjalani rutinitas berobat membuat ia banyak bersyukur menjalani hidup hingga menganggap bahwa sakit ini adalah ujian yang datangnya dari Allah SWT. Menyadari hal ini, Odapus Renti sering menjalin komunikasi (berdoa) pada Allah SWT. Di samping itu, ia juga menjalani hidup dengan banyak memberikan dorongan positif di lingkungan sosial sesama Odapus. Tidak hanya sesama Odapus, ia juga memberikan motivasi kepada teman-teman lain yang masih sehat untuk selalu menjaga kesehatan dan tidak lupa untuk selalu berdoa. Hal-hal seperti inilah yang membuat Odapus Renti sadar diri dan banyak bersyukur akan arti kehidupan.

Jika membuka mata hati dan berfikir jernih, maka kita akan mendapatkan hikmah dibalik rasa sakit yang kita alami seperti firman Allah; Boleh jadi kamu membenci sesuatu, padahal ia amat baik bagimu.

"Boleh jadi pula kamu menyukai sesuatu padahal ia amat buruk bagimu; Allah mengetahui, sedangkan kamu tidak mengetahui." (Q.S Al-Baqarah: 216).

Sakit merupakan kondisi yang dapat memacu kita untuk mempersiapkan akhir kehidupan yang baik. Odapus Renty memaknai sakit lupus sebagai ujian dari Allah SWT. Jika seseorang merasakan perasaan dengan rasa sakit, maka akan mengganggu psikis dan melemahkan daya tahan tubuh terhadap sakit, sehingga membuat individu sulit untuk menyembuhkan dirinya. Sebagai manusia kita memiliki berbagai reaksi emosi yang terkadang harus diperlihatkan atau tidak; semangat, optimis, sabar, tertutup dan semua hal itu hanya sekedar pengetahuan dan pengalaman, sedangkan keimanan pada Allah SWT menjadi penentu untuk memberikan kesembuhan. 
Terkait komunikasi kesehatan dalam kajian Islam, penyakit merupakan ujian yang diberikan Allah kepada umatnya untuk diuji keimanan. Seperti ayat dibawah ini yang peneliti kutip dalam alquran ;

"Tiap-tiap yang berjiwa akan merasakan mati. Kami akan menguji kamu dengan keburukan dan kebaikan sebagai cobaan (yang sebenar-benarnya). Dan hanya kepada Kamilah kamu dikembalikan." (Q.S Al-Anbiya: 35).

Seperti yang juga diungkapkan oleh informan kedua Odapus Nancy, mengganggap dan memaknai sakit lupus ini sebagai bentuk ujian dan teguran dari Allah. Memang pada awalnya ia mengaku kecewa dan marah pada Sang Pencipta, karena kehidupan Odapus Nancy sebelum terdiagnosa lupus berlimpah dengan kemewahan, apa yang diinginkan langsung ia dapatkan. Namun berbeda ketika ia menjadi Odapus, ia merenungi segala yang terjadi dalam hidupnya. Di dalam hatinya ia belajar untuk bisa menerima, bersyukur dan ikhlas atas apa yang terjadi. Sehingga proses pemaknaan lupus memberikan perubahan dalam hal keimanan dan pola konsumsi.

Meskipun Odapus Nancy sempat mengalami kekecewaan, ia berusaha mencoba untuk menerima semuanya. Karena ia mengganggap apa yang terjadi adalah kehendak dari yang maha kuasa, seperti ayat yang peneliti kutip berikut ini;

"Apabila aku sakit, Dialah yang menyembuhkanku, dan yang akan mematikan aku, kemudian menghidupkan aku kembali" (Q.S. Asy-Syu'ar': 80-81)

Senada dengan informan ketiga yakni Odapus Diana. Ia mengatakan bahwa pada saat terdiagnosa lupus merasa terpuruk dengan keadaan, karena dengan kondisi masih muda dan memiliki anak-anak yang masih kecil membuat ia putus asa. Seiring berjalan nya waktu dengan rutin berobat, banyak hikmah yang ia ambil pelajaran dalam hidupnya yakni berfikir tentang tujuan manusia diciptakan oleh Allah. Dengan begitu ia dan suaminya belajar untuk berproses menerima penyakit lupus. Perubahan yang dilakukan Odapus Diana dan pasangannya dimulai dari cara berfikir dalam menjalani hidup, seperti mengubah gaya hidup yang lebih sehat dan mengubah cara mereka dalam menjalin komunikasi sebagai pasangan suami istri.

Terkait dengan hidup sehat, Nabi Muhammad Saw pun menjalani gaya hidup sehat. Nabi Muhammad Saw menjaga kesehatan dengan cara preventif (pencegahan) dan kuratif (pengobatan), hal ini sejalan dengan kajian komunikasi kesehatan. Sehingga komunikasi kesehatan dalam Islam mengajarkan pemeliharaan kesehatan seperti menjaga kebersihan. Kebersihan dalam Islam tidak hanya meliputi kebersihan secara fisik tetapi juga kebersihan jiwa (dominan dalam alquran), sehingga umat Islam dapat membersihkan jiwa. 
"Hai manusia, sesungguhnya telah datang kepadamu pelajaran dari Tuhanmu dan penyembuh bagi penyakit-penyakit dalam dada, dan petunjuk serta rahmat bagi orangorang yang beriman." (Q.S. Yunus: 57)

Dalam hidupnya, Odapus Diana menyadari bahwa penyakit lupus yang didapatinya sebagai penggugur dosa, karena selama hidupnya ia merasa penuh dengan dosa. Hanya saja ia tidak mau berfikir negatif dan mengalihkan pada hal positif sehingga ia menganggap Lupus sebagai hadiah dan rejeki, karena tidak semua orang bisa mendapatkan penyakit ini. Berdasarkan uraian Odapus Diana, ia mencoba untuk mengganti hal-hal negative menjadi positif. Sehingga dalam perjalanan hidup, jiwa dan pikiran positif selalu mengikutinya.

Untuk meraih ketenangan dalam hidup tentu kita harus selalu ada pada pola pikir positif misalnya kegiatan individu diisi dengan hal-hal baik (mengingat Allah) maka kebaikan pula lah yang akan didapat. Sesuai dengan surat yang peneliti kutip;

"Hai orang-orang yang beriman, ingatlah kepada Allah SWT, dengan mengingat sebanyak-banyaknya." (QS. Al-Ahzab: 41)

Kondisi dan suasana hati yang positif akan memberikan pengaruh pada sistem kekebalan tubuh, karena jika terdapat pikiran yang negative akan melemahkan sistem kekebalan tubuh. Sistem imun dapat melemah diakibatkan pikiran dan emosi yang menyatu dan berpengaruh pada kondisi fisik tubuh. Seperti yang diungkap oleh Black $\mathrm{PH} 27$ dalam tubuh memiliki seperangkat sistem susunan saraf pusat dan sistem imun, keduanya berinteraksi yang diperantarai oleh aksis HPA (Hipotalamus-Pituitary-Adrenal). Sehingga dalam tubuh terjadi komunikasi dan saling interaksi antara sistem saraf dan immune networks, yang mana kondisi psikis dan perilaku bergantung pada imunitas. Hal ini disebabkan proses imun dapat mempengaruhi perilaku dan kondisi psikis.

Adanya lupus dalam kehidupan Odapus membuat pengalaman Odapus berbeda ketika menjalani hidup dengan lupus. Pada informan Renti, ia mengalami keluar masuk rumah sakit hingga hampir mengalami depresi. Lain halnya pada Odapus Nancy, Lupus membuat dirinya shock dan marah terhadap Allah karena penyakit yang ia dapat, sedangkan Odapus Diana mengganggap bahwa ini merupakan hadiah dari Allah SWT. Masing-masing Odapus memiliki interpretasi dan persepsi yang berbeda terhadap penyakit Lupus.

Ketika awal terkena lupus dan memaknai sakit lupus adalah bagian dari kehidupan para Odapus, pengalaman masing-masing Odapus membuat mereka sadar diri bahwa sesungguhnya kehidupan adalah milik Allah SWT. Pemaknaan sakit lupus pada Odapus merupakan bagian

${ }^{27}$ Puji., hlm. 325 
penting dalam menjalani proses sakit mereka, karena dengan memaknai sakit lupus inilah mereka dapat memberikan opini atau pandangan mereka akan arti hidup yang sesungguhnya. Makna sakit lupus yang dilakukan para Odapus tentu memiliki dampak perubahan pada kehidupan Odapus. Odapus Renti yang lebih dari sepuluh tahun menjadi Odapus, lebih banyak berfikir positif dalam memandang hidup, ia sadar bahwa hidup yang dijalani tidak seperti dulu lagi dan menganggap lupus adalah ujian baginya dalam hidup sehingga terjadi perubahan diri dalam hal keimanan.

Odapus Nancy memaknai penyakit lupus sebagai teguran karena selama hidup pernah berbuat salah, akhirnya ia mengubah perilaku dalam kesehariannya seperti mengikuti kegiatan pengajian rutin dimasjid, sering mengunjungi teman sakit dan selalu berinteraksi dengan tetangga dekat rumahnya. Hal yang sama juga dirasakan oleh Odapus Diana, Lupus memiliki makna tersendiri dalam hidupnya sebagai anugerah yang berdampak pada hidup sehat dan menjalin komunikasi yang lebih intens pada pasangan sehingga mereka menjadi lebih terbuka dan jujur.

Lupus memang salah satu penyakit autoimun yang banyak ditakuti oleh semua orang, apalagi jumlah Odapus yang makin meningkat membuat masyarakat awam takut mendengar kata Lupus. Kita memang tidak dapat menghindari sebuah penyakit. Untuk itu, ketika seseorang mendapatkan sebuah penyakit (apapun itu), perlu untuk direnungi dan berfikir bahwa kematian tidak dapat dihindari dan mengingat kembali bahwa tujuan kehidupan adalah pada yang maha kuasa. Terkait hal ini, Pemaknaan sakit memang melibatkan kondisi psikis dan fisik. Terutama mental, Abidin berpendapat bahwa manusia dipandang memiliki dua aspek yang meliputi aspek perilaku dan aspek pengalaman.28 Para Odapus ini mengalami penderitaan melalui sakit lupus dengan melewati berbagai pengalaman sakit dan menjadikan proses ini untuk memaknai sakit mereka.

Dari hasil wawancara peneliti pada ketiga informan, terlihat bahwa untuk menerima penyakit ini butuh waktu dan proses yang cukup Panjang. Ketiga informan ini menjadi sampel bagi peneliti bahwa mereka sebagai penyandang lupus juga manusia biasa untuk mengeluh, kecewa dalam hidup dan hal ini merupakan bentuk emosi yang mereka utarakan ketika menghadapi penyakit. Namun, seiring berjalannya waktu, ketiga informan ini berproses dan

\footnotetext{
${ }^{28}$ Imam \&Indah," Makna sakit pada penderita jantung coroner “, Jurnal Psikologi UNDIP, vol.13 no. 1, 2014.hlm.8
} 
merefleksikan diri dengan cara melakukan komunikasi dalam diri mereka. Banyak hal yang dirasakan oleh ketiga informan terutama pada perubahan perilaku dalam menerima diri seperti sabar, optimis sembuh, bahagia dan melakukan hal-hal positif.

Dalam pandangan Islam, imun yang ada ditubuh manusia menjadi sebuah anugerah yang diberi dengan tujuan untuk keberlangsungan hidup umat manusia. Sebagai seorang muslim, tentu ibadah menjadi hal utama bagi mereka untuk berfikir dan mengingat kembali atas apa yang telah terjadi pada mereka. Sehingga masing-masing informan pada akhirnya menyerahkan masalah pada Allah SWT dan berusaha bangkit dengan cara rutin berobat medis dan non medis. Dengan usaha yang telah dilakukan membuat ketiga informan ini tidak berputus asa, dan mendapatkan dukungan dari berbagai pihak. Ketiga informan tersebut semangat dalam menjalani hidup mereka masing-masing. Adanya harapan didalam hidup, membuat Odapus memiliki semangat dalam menjalankan kehidupan. Berdasar hadist yang peneliti kutip terkait semangat hidup;

"Bersemangatlah melakukan hal yang bermanfaat untukku dan meminta tolonglah pada Allah SWT, serta janganlah engkau malas" (HR. Muslim)

Autoimun dapat menyerang siapa saja tanpa melihat suku, ras atau agama. Bahkan penyakit autoimun tak mengenal perempuan atau laki-laki untuk diserang. Apalagi jenis autoimun begitu banyak dan salah satunya lupus yang berdampak pada fisik dan mental. Sebagai penyandang lupus, bersabar menjadi sahabat dalam raga mereka (Odapus). Seperti ungkapan sayyidina Ali Bin Abi Thalib r.a.

"Jika engkau bersabar, takdir akan tetap berlaku bagimu, dan engkau akan mendapatkan pahala. Jika engkau berkeluh kesah, takdir juga akan tetap berlaku bagimu, dan engkau akan mendapatkan dosa."

Bagi mereka yang awal terkena lupus akan membuat Odapus menghadapi berbagai dilema seperti stres, depresi hingga bunuh diri. Dalam Islam, ketika seseorang memilih untuk bunuh diri akibat tidak kuat menahan penderitaan (sakit) dalam hidup mereka maka ia tidak bernilai. Dengan begitu, sebagai manusia yang telah diberi akal oleh pencipta harus memiliki sikap dalam diri agar kita dapat mengambil pelajaran dan nilai yang saat ini sedang kita hadapi. Disaat kita merenungi dan berfikir dengan apa yang terjadi dalam hidup maka aspek spiritual yang ada dalam diri manusia berfungsi dan menggerakkan emosi dan pikiran untuk bisa bersatu dan membangkitkan diri untuk kembali semangat dalam menjalani hidup.

Dalam alquran, konsep mengenai komunikasi kesehatan terdapat pada pentingnya perubahan perilaku manusia secara sehat. Begitupun dengan fungsi alquran sebagai petunjuk, penjelas, pembeda, maudziah, rahmah dan obat. Kita ketahui bahwa perilaku sehat diawali 
dengan pemahaman sehat yakni sehat secara fisik, rohani dan spiritual. Senada dengan hal itu, sehat menurut organisasi WHO ialah dalam keadaan sempurna baik jasmani, rohani dan kesejahteraan sosialnya. Sehingga dalam memenuhi ketiga hal ini maka diperlukan relasi yang saling mendukung antara lain komunikasi spiritual, emosi, komunikasi sosial serta lingkungan yang sehat pula.

Terkait dengan imunitas tubuh manusia, adanya sistem kerja imunitas tubuh menjadi salah satu anugerah yang diciptakan oleh Allah SWT untuk kehidupan manusia. Hal ini bisa dikatakan bahwa Allah yang menciptakan dalam diri manusia karena terdapat ayat-ayat kekuasaan allah. Dengan demikian, para informan yang peneliti temui lebih banyak merenungi akan nilai-nilai kehidupan dalam keadaan mereka menghadapi autoimun lupus salah satunya dengan cara berkomunikasi dengan Allah melalui ibadah shalat lima waktu, karena dengan beribadah membuat para informan lebih tenang dan ikhlas menerima semua. Dari beberapa penelitian terkait pun, banyak peneliti dan ilmuwan barat mengungkapkan bahwa aspek religiusitas (shalat, zikir) memiliki dampak positif seperti memperkuat sistem imun dan mengembalikan kesehatan pada mereka yang terkena penyakit salah satunya autoimun. ${ }^{29}$

Terkait dengan komunikasi kesehatan intrapersonal, makna sakit menjadi sebuah proses simbolik pada diri Odapus secara subjektif, sehingga Odapus menerima kondisi yang berasal dari pengalaman, pengetahuan dan keyakinan. Pemaknaan atau makna sakit menjadi bagian penting dalam menghadapi proses sakit pada Odapus, dengan memberikan pemahaman atau makna pada sakit akan memberikan mereka pandangan terhadap kondisi masing-masing Odapus. Untuk itu menurut Frankl, makna dalam hidup bersifat objektif karena menantang manusia untuk meraihnya. Fenomena imunitas saat ini menjadi hal yang banyak diperbincangkan, berbagai faktor pun masih sulit untuk menetapkan apa yang menyebabkan seseorang menderita penyakit autoimun khususnya Lupus. Dengan begitu, makna sakit yang dihadapi Odapus menjadi sebuah hal berharga dan nilai bagi mereka untuk dapat meningkatkan kualitas dalam hidup terkait dengan tujuan Odapus dalam kehidupan.

Manusia merupakan ciptaan Allah yang begitu luar biasa, untuk itu ketika kita mendapatkan sebuah penyakit maka kita wajib untuk berusaha dan berdoa agar kita diberikan kebaikan. Disatu sisi Odapus merasa tertekan dan lelah melihat pengalaman hidup yang mereka jalani, hanya saja tidak seluruh Odapus memandang penyakit Lupus dengan pandangan buruk, sebaliknya memberikan pikiran positif terhadap penyakit tersebut. Masalah adalah sesuatu yang pasti dalam hidup manusia, karena masalah adalah ujian dari Allah termasuk sakit, yang mana

\footnotetext{
${ }^{29}$ Uud.,hlm.64.
} 
untuk menguji tingkat keimanan manusia dan mendorong untuk menjadikan agama sebagai solusi dalam menyelesaikan masalah. Dengan demikian, para Odapus Bengkulu memaknai lupus sebagai bagian perjalanan kehidupan mereka dan memberikan perubahan dalam hal keimanan dan gaya hidup. Selain itu, makna lupus bagi Odapus sebagai ujian dalam meningkatkan keimanan agar mereka menjadi manusia yang bernilai dan berkualitas ketika menghadap sang pencipta.

\section{KESIMPULAN}

Memaknai hidup tidak hanya dalam keadaan bahagia, akan tetapi disaat kondisi sakit makna begitu berperan dalam kehidupan individu manusia untuk mencapai tujuan hidup. Seperti para penyandang autoimun lupus, penyakit yang mereka dapatkan membuat Odapus berkomunikasi dengan diri sendiri dan memikirkan apa yang telah diberikan Allah SWT. Sehingga, Odapus menjadikan lupus bukan sebagai beban melainkan meringankan penyakit tersebut. Berdasarkan uraian dari pembahasan yang telah dijelaskan oleh peneliti, maka makna sakit lupus bagi Odapus dilihat secara positif dan membuat Odapus bersemangat memiliki harapan untuk menjalani hidup.

Dalam pandangan komunikasi kesehatan Islam, komunikasi intrapersonal menjadi sumber kekuatan bagi Odapus dalam memaknai hidup. Makna Lupus bagi Odapus memberikan perubahan dalam hal keimanan, pola perilaku dan pola konsumsi. Dari sisi kehidupan sosialagama; para Odapus mengikuti kegiatan keagamaan untuk memberikan ketenangan hati sehingga hidup menjadi lebih bermakna untuk tetap semangat menjalani hidup. Makna sakit lupus juga memberikan perubahan perilaku Odapus, dari yang suka kemewahan membuat Odapus lebih mementingkan akhirat dibandingkan duniawi. Kemudian dari pola konsumsi tentu ketiga Odapus menjaga makanan agar tubuh berimbang. Ketika seseorang mengalami sakit, maka sisi spiritual manusia akan muncul dan dimensi rohani menjadi sumber kekuatan dan kesehatan untuk menjadi berkualitas dengan menemukan makna sakit pada hidup mereka. Dengan demikian, sebagai manusia kita perlu memaknai pengalaman yang di alami setiap hari dalam kondisi apapun baik dalam keadaan sehat atau sakit.

\section{REFERENSI}

Agustina, Septa. Komunikasi Interpersonal Odapus dan Keluarga. Tesis, Bengkulu: Universitas Bengkulu, 2019. 
Ahyani., Regulasi Emosi Odapus, Jurnal Psikologi Undip Vol. 8 No. 1, 2012.Bastaman, H. D., Logoterapi: Psikologi untuk menemukan makna hidup. Jakarta: Grafindo, 2007.

American Autoimmune Related Disease Association. 2010. Autoimmune Statistic. http://aarda.org/autoimmune-information/autoimmune-statistic/. DIakses 7 April 2020

Benedikta, "Minim Informasi Gejala Lupus Jarang Disadari", https://www.liputan6.com/health/minim-informasi-gejala-lupus-jarang-disadari .Diakses Minggu 4 Maret 2018

Emzir., Metodologi Penelitian Kualitatif: Analisis Data. Jakarta: Rajawali Pers, 2018.

Fandika, Rizky Ayu., Hubungan Keparahan Penyakit, Aktivitas dan Kualitas Tidur Pasien SLE", Unnes Journal of Public Health, Vol. 5. No. 3. 2016.

Fatmawati, Atikah., Regulasi Diri pada Penyakit Kronis-SLE: Kajian Literatur," Jurnal Keperawatan Indonesia, Vol. 21, No. 1, 2018.

Ganjar, Agus., Memetakan Komunikasi Kesehatan. Observasi Kajian Komunikasi dan Informatika. Vol. 7, No. 1, 2009.

Judha, M., Pencarian Makna Hidup Klien Terdiagnosa Lupus Eritematosus Sistemik Dengan Perspektif Maslow dan Henderson. Jurnal Keperawatan Indonesia, Vol. 13. No. 3, 2010.

Katherine, Castle., Illness Narratives of Woman With SLE, Disertation, Amerika: University of Nebraska-Lincoln, 2015.

Kriyantono, Rahmat., Riset Komunikasi. Jakarta: Kencana, 2014.

Lestari, Siska., Ahmad Mujab., Ketabahan Pada Wanita Penderita Lupus, Jurnal Psikologi UNDIP, Vol. 3 No. 2. 2014.

Mulyana, Deddy., Komunikasi Kesehatan: Pemikiran dan Penelitian. Bandung: Rosdakarya, 2018.

Pusdatin,"Situasi Lupus di Indonesia", Infodatin-Kemenkes. Januari 2017. https;/ / www.Infodatin-kemenkes.com diakses 11 Nov 2017

Rahmawati, Puji., Hanafi Muljohardjono., Meaning of Illness dalam Perspektif Islam. Jurnal Komunikasi Islam Vol. 6. No.2, 2016.

Rakhmat, Jalaludin., Psikologi Komunikasi. Bandung: Remaja Rosdakarya, 2012.

Sly, "Tidak kuat derita penyakit", Rakyat Bengkulu. 1 Agustus 2018. www.HarianRakyatBengkulu/Tidak-kuat-menderita-penyakit. Diakses 3 Agustus 2018

Tty,"Lupus Yang Misterius", Okezone.15 Mei 2008.

https://lifestyle.okezone.com/lupus-yang-misteriusz. Diakses 5 Agustus 2018

Wahyuningsih, Agustin., Kesejahteran Psikologis Pada Odapus Wanita Usia Dewasa Awal Berstatus Menikah, Jurnal Psikologi Klinis dan Kesehatan Mental, Vol. 1, No. 3, 2012. 